\title{
Evaluation of the influence of the genetic background in tissue repair in diabetic mice
}

\author{
Simone Aparecida de Almeida*, Silvia Passos Andrade, Paula Peixo Campos Lopes, Laura Alejandra Ariza Orellano, \\ Celso Tarso Rodrigues Viana, Luciana Xavier Pereira, Mônica Alves Neves Diniz Ferreira \\ From 20th Brazilian Diabetes Society Congress \\ Porto Alegre, Brazil. 11-18 November 2015
}

\section{Background}

Studies with genetically different strains of mice showed different responses for diabetes, glucose levels and insulin levels. Several experimental models have shown that wound healing and angiogenesis are phenotypes dependent on the collection of genes present in an organism. However, we found no study that investigated the influence of genetic heterogeneity in the process of inner healing in diabetic animals.

\section{Objectives}

Evaluate the influence of genetic background in the components of repair process (angiogenesis and inflammation) induced by synthetic matrix in mice with type I diabetes (Swiss, Balb/C and C57).

\section{Materials and methods}

Angiogenesis and inflammation were assessed at 10 days after implantation in polyether-polyurethane sponge discs implanted subcutaneously in female Swiss, C57, and Balb/c control and diabetic mice induced by streptozotocin (STZ; $\mathrm{n}=10)$.

\section{Results}

The strains responded distinctly to the diabetogenic treatment as assessed by fasting glucose levels (Swiss $\mathrm{CT}=134.0 \pm 3.8$ vs $\mathrm{STZ}=455.4 \pm 14.51 ; \mathrm{C} 57 \mathrm{CT}=135.4 \pm 6.2$ vs $\mathrm{STZ}=393 \pm 21.7 ; \mathrm{Balb} / \mathrm{c} \quad \mathrm{CT}=118.4 \pm 4.0$ vs $\mathrm{STZ}$ 190.0 \pm 10.46$)$. Hemoglobin content, $(\mu \mathrm{g} / \mathrm{mg})$ in implants of Swiss diabetic animals decreased by $59 \%$ compared with the control group. The diabetogenic treatment did not alter this parameter in the other two strains. In all strains the number of vessels was decreased in implants of diabetic animals compared with their control groups (Swiss CT $=47.5 \pm 14.8$ vs STZ $=6.5 \pm 3.5$; $\mathrm{C} 57 \mathrm{CT}=47.5 \pm 6.2$ vs $\mathrm{STZ}=5.0 \pm 1.9 ; \mathrm{Balb} / \mathrm{c} \mathrm{CT}=39.5 \pm 11.4$ vs $\mathrm{BSTZ}$ $10.0 \pm 3.5)$. In contrast, VEGF levels $(\mathrm{pg} / \mathrm{mg})$ were increased in implants of Swiss and C57/BL diabetic mice The inflammatory parameters (MyeloperoxidaseMPO; N-acetyl-B-D-glucosaminidase-NAG and NO) were markedly influenced by the genetic background. In implants of Swiss and Balb/c diabetic animals, MPO increased, but NAG activity was lower in implants of Swiss diabetic mice. Furthermore, the levels of nitric oxide were also reduced in implants of the all diabetic mouse strains. The inflammatory cytokines (TNF, CCl2 and $\mathrm{KC}$ ) also showed distinct profiles after the diabetogenic treatment.

\section{Conclusion}

The genetic background influenced the systemic and local response to the diabetogenic treatment in the strains of mice evaluated. Swiss mice were the most affected strain analyzed whereas the least was the Balb/ c. These important strainrelated differences to diabetes must be considered in the design and analysis of studies internal healing hyperglicemic environment.

Published: 11 November 2015

doi:10.1186/1758-5996-7-S1-A244

Cite this article as: de Almeida et al: Evaluation of the influence of the genetic background in tissue repair in diabetic mice. Diabetology \& Metabolic Syndrome 2015 7(Suppl 1):A244.

* Correspondence: si.almeida19@gmail.com

Universidade Federal de Minas Gerais, Belo Horizonte, Brazil 